\title{
The Compulsory Pilot Defense: A Reexamination of Personification and Agency
}

Statutes in many states require shipowners to accept the services of a licensed pilot who is assigned to each ship upon its entering a harbor. ${ }^{1}$ Collisions between vessels ${ }^{2}$ caused solely by the negligence of such "compulsory pilots" are governed by separate and distinct rules of liability under admiralty and the common law. The damaging vessel will be liable for damages in an in rem admiralty libel, ${ }^{3}$ but the shipowner cannot be held personally liable in an action at common law. ${ }^{4}$ In some cases, this inconsistency may determine the adequacy of the injured party's remedy. For example, if the vessel steams out of the jurisdiction before it has been served in rem, it may escape service and liability altogether. ${ }^{5}$ The injured party's remedy would be more adequate if the common law permitted an in personam action against the shipowner, who would presumably be easier to serve with process.

The enigma of holding a vessel liable in the absence of an underlying personal liability of its owner results from an application of the personification theory of maritime liens. ${ }^{6}$ Four federal

1. See statutes collected in Comment, Employer's Liability for Employee He Was Compelled to Hire, 16 Clev.-Mar. L. Rev. 541, 542 n.10 (1967). The vessel must accept the services of the first pilot who offers his services through a signaling process known as "speaking" the vessel, or pay a penalty. A. Parks, Law of Tug, Tow and Pilotage 509-10 (1971).

2. The only collisions under consideration in this comment are those that occur in the pilotage grounds, generally in the outer harbor of a port, where a pilot is in control of the ship. That control is usually terminated in the inner harbor, where tug captains execute docking operations under independent rules of liability for negligently caused collisions. Throughout this comment, "harbor collisions" will be used to refer only to collisions in the pilotage grounds.

3. The China, 74 U.S. (7 Wall.) 53 (1868).

4. Homer Ramsdell Transp. Co. v. La Compagnie Générale Transatlantique, 182 U.S. 406 (1901).

5. See Tube Prods. of India v. S.S. Rio Grande, 334 F. Supp. 1039 (S.D.N.Y. 1971) (complaint dismissed where owner's defense to in personam suit held good and no process served on vessel). Service may involve prohibitive cost if, for example, it must be accomplished in a foreign port.

6. See Toy, Introduction to the Law of Maritime Liens, 47 TuL. L. REv. 559, 563 (1973). The personification theory treats the ship as a juridical entity and has three distinct consequences: "(1) the maritime lien should attach irrespective of any personal obligation of the owner; (2) the limit of liability in an action in rem based on the existence of a maritime lien must be the value of the ship; and (3) the lien would remain indelible notwithstanding any change in ownership." Hebert, The Origin and Nature of Maritime Liens, 4 Tul. L. Rev. 381,383 (1930). 
courts of appeals have rejected the virtual paradox, in contexts other than collisions caused by compulsory pilots, and have required in personam liability as a prerequisite to the liability of a vessel. ${ }^{7}$ In doing so these courts have abandoned the personification theory, once viewed as "almost an intellectual necessity," in favor of an analysis that views the distinction between rights of action at law and admiralty as procedural and thus substantively nondeterminative. ${ }^{9}$ Moreover, in eliminating the distinction between rules of liability by rejecting the personification doctrine, they have necessarily established the common law rule as the one to be consistently applied.

Although the Supreme Court has clearly been presented with the enigma in two recent cases, ${ }^{10}$ it avoided it on both occasions by reversing the lower court's holding that no personal liability existed. ${ }^{11}$ In another recent case, Calero-Toledo v. Pearson Yacht Leasing Co., ${ }^{12}$ the Court upheld the statutory forfeiture of a ship

7. See United States v. Bissett-Berman Corp., 481 F.2d 764 (9th Cir. 1973); Reed v. The Yaka, 307 F.2d 203 (3d Cir. 1962), rev'd on other grounds, 373 U.S. 410 (1963); Pichirilo v. Guzman, 290 F.2d 812, 814 (1st Cir. 1961), rev'd on other grounds, 369 U.S. 698 (1962); Noel v. Isbrandtsen Co., 287 F.2d 783 (4th Cir.), cert. denied, 366 U.S. 975 (1961). See also Ramos v. Contınental Ins. Co., 493 F.2d 329 (1st Cir. 1974); Ramos v. Beauregard, Inc., 423 F.2d 916 (1st Cir.), cert. denied, 400 U.S. 865 (1970); Alcoa S.S. Co. v. Rodriguez, 376 F.2d 35 (1st Cir.), cert. denied, 389 U.S. 905 (1967). Other courts of appeals have accepted the paradox. See, e.g., Grigsby v. Coastal Marine Serv., Inc., 412 F.2d 1011 (5th Cir. 1969); Grillea v. United States, 232 F.2d 919 (2d Cir. 1956). For a lucid discussion of the conflicting views, see Richards, Maritime Liens in Tort, General Average, and Salvage, 47 Tul. L. Rev. 569, 576-79 (1973). See also Comment, Developments in the Law of Maritime Liens, 45 Tul. L. Rev. 574, 590-91 (1971).

8. The Underwriter, 119 F. 713, 722 (D. Mass. 1902) (Lowell, J.).

9. The procedural theory of liens implies the following conclusions: "(1) there may be a right to proceed in rem regardless of the existence of a maritime lien; (2) the proceeding in rem based on a maritime lien is in substance an action against the owner of the vessel and the vessel is not liable unless the owners are personally liable; and (3) the recovery in an action in rem is not limited to the value of the res where the defendant has appeared to defend the suit in rem." Hebert, supra note 6 , at 385 .

10. See Reed v. The Yaka, 373 U.S. 410 (1963); Guzman v. Pichirilo, 369 U.S. 698 (1962). The Supreme Court has long recognized the existence of an "abiding riddle" in imposing liability on the vessel but not its owner, but has failed to resolve it. See, e.g., The City of Norwich, 118 U.S. 468, 503 (1886); Consumers Import Co. v. Kabushiki Kaisha Kawasaki Zosenjo, 320 U.S. 249, 253 (1943).

11. In Guzman, the Court reinstated the trial court's rejection of the shipowner's personal defense, and noted that it therefore did not need to consider the holding of the court of appeals that the vessel could not be liable when the shipowner's defense was valid. 369 U.S. at 700 n.3. In Reed, the Court stated that it had granted certiorari specifically because it had previously reserved in Guzman the question of whether personal liability was essential to the liability of a ship. But the Court found that the court of appeals had erred in holding that there was no personal liability for the injury to the plaintiff longshoreman, and the question was again avoided. 373 U.S. at 411-12.

12. 416 U.S. 663 (1974). 
despite the fact that the ship's owner was innocent of any wrongdoing. ${ }^{13}$ The majority opinion in Calero-Toledo reaffirms the concept of independent liability of a vessel in the unique case of forfeitures, but leaves open the question of whether independent liability can exist in other circumstances under a general theory of personification. ${ }^{14}$

The undesirability of maintaining the personification fiction ${ }^{15}$ compels a reexamination of the bases of the rules of liability for collisions caused by the sole negligence of compulsory pilots. This comment first examines the cases that established those rules, both to expose the issues underlying the cases and to suggest the actual grounds of the decisions. It then considers the legal and policy issues to determine what the rule of liability should be, and concludes that the shipowner should be held liable whether the action is at law or in admiralty. Although this results in a rule like that currently existing in admiralty ${ }^{16}$ rather than the contrary common law rule that courts generally have adopted as a natural consequence of rejecting the personification doctrine, it is supported by independent historical, legal and policy analysis instead of a conclusory application of the personification fiction.

13. Id. at 683 .

14. Justice Story's language in The Palmyra, 25 U.S. (12 Wheat.) 1, 14-15 (1827), and in United States v. Brig Malek Adhel, 43 U.S. (2 How.) 210, 233 (1844), is commonly quoted in conjunction with a citation to United States v. The Little Charles, $26 \mathrm{~F}$. Cas. 979 (No. 15,612) (C.C.D. Va. 1818) (Marshall, Circuit Justice), to form "the usual trio of old forfeiture cases." See G. Gilmore \& C. Black, The Law of Admiralty 495 (1957) [hereinafter cited as GILMORE \& BLACK]. Gilmore and Black think it apparent from those opinions "that neither Marshall nor Story was thinking of admiralty law except in the loosest possible analogy and that no 'principle' of admiralty law was being laid down." Id. at 487-88. Since Calero-Toledo was indeed a forfeiture case, direct reference to the language in two of the three classic forfeiture cases, see 416 U.S. at 683-84, was proper, and Calero-Toledo might be read as not reasserting the personification theory except in that limited context. But the Supreme Court has relied on the classic forfeiture opinions as the basic authority for the broader personification theory of maritime liens. See The Barnstable, 181 U.S. 464 (1901); Richards, supra note 7, at 579.

15. See Gilmore \& Black, supra note 14, at 510. Besides the modern view that the use of legal fictions should be curtailed where it is possible to substitute legal and policy analysis as a ground for decision, the inconsistent rules produced by the use of the personification theory in the compulsory pilot cases may deny an injured plaintiff adequate relief. Although an application of legal and policy analysis need not reach an opposite rule, it is argued in this comment that such analysis supports a consistent rule of shipowner liability.

16. A shipowner can limit his liability to the value of the vessel and the freight then pending by petitioning a federal district court, whether the action is originally brought in personam at admiralty or in a common law court. 46 U.S.C. $\$ \S 183($ a), 185 (1970). Disallowing the compulsory pilot defense, then, would result in a personal liability that is only equivalent to the owner's loss of his ship in an in rem proceeding. The advantages of this change lie in the desirability of having a consistent judicial rule of liability and of rejecting the personification fiction as a basis for that rule. 


\section{The Major Gompulsory Pilot Cases}

The inconsistent treatment of the compulsory pilot defense arose from the early Supreme Court decisions confronting the issue. To be properly understood, those cases must be read in their historical context. Throughout the nineteenth century, a number of cases and treatises probed the issue of the compulsory pilot defense, and their approach to the problem rests on several considerations that no longer clearly emerge in legal literature. A contextual analysis of the three important American decisions not only illuminates the disparate legal reasoning and policy preferences, but also points toward a solution.

\section{A. The Creole (1853)}

A federal appellate court first dealt with the pilotage defense in 1853 in Smith $v$. The Creole, ${ }^{17}$ a case in admiralty. Legal writers who had considered the pilotage defense prior to The Creole were confronted with numerous British precedents but only three significant American decisions, all at the state court level. ${ }^{18}$ The language of these decisions indicated that the state courts intended to subject the shipowner to liability even though the pilot was not his voluntarily chosen servant. ${ }^{19}$ In their treatises, George Curtis and Joseph Story disapproved that view and accepted instead the prevailing British rule of nonliability for the negligent acts of a compulsory pilot, finding it "only conformable to a principle of natural justice" to exempt the shipowner when his choice of a pilot was not free. ${ }^{20}$

But Justice Grier, writing the opinion in The Creole, entertained quite different views about natural justice and the principles of vicarious liability. In Philadelphia E Reading R.R. v. Derby, ${ }^{21}$ he had already demonstrated a commitment to the view that the rule of respondeat superior was capable of almost universal application and that excessive qualification of the maxim would tend to nullify it and to render the remedy of the injured party illuso-

17. 22 F. Cas. 497 (No. 13,033) (C.C.E.D. Pa. 1853). There was apparently an earlier case dealing with the defense, since Justice Grier expressed his agreement with a prior decision by Justice Wayne sitting in another circuit, $i d$. at 508 , but no specific reference to the case was given.

18. Bussy v. Donaldson, 4 U.S. (4 Dall.) 194 (Pa. 1800); Williamson v. Price, 4 Mart. (N.S.) 399 (La. 1826); Yates v. Brown, 25 Mass. (8 Pick.) 22 (1829).

19. 4 U.S. (4 Dall.) at 194-95; 4 Mart. (N.S.) at $400 ; 25$ Mass. (8 Pick.) at 23-24.

20. G. Curtis, a Treatise on the Rights and Duties of Merchant Seamen 197 (1841); J. Story, Commentaries on the LAW of Agency as a Branch of Commercial and MARITIME JURISPRUdence $\S 456$ a (3d ed. 1846).

21. 55 U.S. (14 How.) 468 (1852). 
ry. ${ }^{22}$ His Creole opinion provided an occasion for amplifying and extending his earlier analysis.

Admittedly, the major portion of Justice Grier's opinion technically involved mere dicta. The Pennsylvania statute upon which the shipowner relied actually imposed voluntary rather than compulsory pilotage. ${ }^{23}$ Instead of confining his analysis to the specific legal situation before him, however, Justice Grier approached the question of liability in harbor collisions from the perspectives of common, civil, and maritime law as applicable to both voluntary and compulsory pilots.

First, he recognized that if a colliding vessel guided by a licensed pilot were itself discharged, leaving only the pilot to respond in damages, the injured party would in most cases be denied a remedy. ${ }^{24}$ Furthermore, no American decision either at common law or in admiralty had ever allowed such a discharge. ${ }^{25}$ The Pennsylvania Supreme Court's opinion in Bussy $v$. Donaldson, ${ }^{26}$ he observed, had specifically declared that the pilotage statutes were not intended to obliterate the principle of law holding the owner of a vessel liable for the conduct of the pilot. Justice Grier agreed, noting that the statutory compulsion that supposedly eliminated the relation of master and servant between pilot and owner was "more imaginary than real."27 His implicit conclusion was that principles of respondeat superior rendered shipowners liable at common law.

In the second part of his opinion, Justice Grier turned to principles of maritime law to determine the rights and remedies of the libellants. ${ }^{28}$ Noting that an admiralty proceeding in rem was not "a mere attachment to compel the appearance of the owners," he explained that principles of maritime law had their roots in the usages of the middle ages rather than in civil law doctrines concerning master and servant. ${ }^{29}$ Under these principles, he concluded, third parties were entitled to treat the vessel as primarily liable for the acts of the owner, and in turn for the acts of his pilot, who would be considered the temporary master of the ship no matter how or why he was appointed. ${ }^{30}$ "It cannot be maintained

22. Id. at 487 .

23. Smith v. The Creole, 22 F. Cas. 497,506 (No. 13,033) (C.C.E.D. Pa. 1853).

24. Id. at 505 .

25. Id.

26. 4 U.S. ( 4 Dall.) 194 (Pa. 1800).

27. $22 \mathrm{~F}$. Cas. at 506 .

28. Id. at 507 .

29. Id.

30. Id. 
that the circumstance of having a pilot on board, and acting in conformity with his directions, can operate as a discharge of the responsibility of the owners." 31

\section{B. The China (1868)}

The basic parameters of the compulsory pilot defense changed but little in the years following The Creole. In England, a statutory exemption allowed the elimination of the early inconsistencies of the High Court of Admiralty and courts of common law, firmly establishing the immunity from liability of a wrongdoing vessel in British territorial waters when a compulsory pilot was in charge and alone in fault. The British rule rested, according to Paley in his contemporary treatise on agency law, on the "manifest ground of equity" that since the shipowner did not appoint the pilot, he should not have to answer for acts of negligent navigation. ${ }^{32}$

In the United States, a collision between the steamship China and the brig Kentucky brought the compulsory pilot question to the Supreme Court for the first time. ${ }^{33}$ The underlying question in this admiralty suit was whether to follow the rule established in England or the rule of the American circuit and state courts. The owners of the China relied on the English decisions, stressing the injustice of holding men responsible for the consequences of acts that the law compelled them to perform. They emphasized the considerations of justice and policy underlying the maxim respondeat superior. The libellant countered with policy arguments emphasizing that the British doctrine had never been adopted in the United States. He urged the Court to adopt the views of Justice Grier in The Creole and affirm the liability of the ship. ${ }^{34}$

A close reading of the opinion in The China ${ }^{35}$ discloses that the Supreme Court not only made a clear policy choice but also did so without turning to the old forfeiture cases as a way of personifying the offending vessel. In every essential particular, the opinion of Justice Swayne rested on the earlier examination of the subject

31. Id. at 507-08, quoting The Neptune the Second, 165 Eng. Rep. 1380, 1381 (Adm. 1814). Story had cited The Neptune as countering the prevailing British rule that he incorporated into the main text of his treatise. J. STORY, supra note 20 , at 595 n.l.

32. W. Paley, A Treatise on the Law of Principal and Agent 296-300 (4th Am. ed. 1856). It was duly noted that under the American case law, "independent of statute, the owner is liable for the acts of a pilot, although licensed, as an ordinary agent." Id. at 300 n.8. See also id. at 296 n.g.

33. The China, 74 U.S. (7 Wall.) 53 (1868).

34. Id. at 54-58 (summaries of the parties' arguments).

35. 74 U.S. (7 Wall.) 53 (1868). 
in The Creole. ${ }^{36}$ Like his colleague, Justice Swayne refused to consider the statutory compulsion a sufficient justification for establishing an exemption from the general maxim of respondeat superior. ${ }^{37}$ His opinion indicated his view that the relationship between a compulsory pilot and a shipowner was identical in substance to the relationship between master and shipowner, to which respondeat superior clearly applied. ${ }^{38}$

In adverting to common or civil law principles, Swayne adopted the dictum of the English case The Druid ${ }^{39}$ that the rule must of necessity be the same in admiralty and in common law courts. ${ }^{40}$ Moreover, he agreed with pronouncements in another English case, The Halley, ${ }^{41}$ that the British rule was "fruitful of injustice" and probably "contrary to the fundamental principles of natural right." ${ }^{22}$ A comprehensive survey of British decisions persuaded the majority that there was little inducement to establish the principle of shipowner immunity in American jurisprudence. A rule that allocated sole responsibility to the pilots would provide only an illusory remedy, because in all probability they would be judgment-proof. As between the owners of the damaging vessel and the owners of the innocent vessel, the court thought it "wise and salutary" to throw the loss upon the former. ${ }^{43}$

The majority of the Court made no sustained effort in The China to distinguish common law from maritime principles. It recognized that no American adjudications had reached a contrary result and that a single, contrary rule prevailed in all British courts. Thus, it was not faced with the question of whether disparate rules could be administered in correlative court systems.

36. A close comparison of the structure and reasoning of the two opinions is the strongest authority for this proposition. Swayne's own language provides additional confirmation: "In the case of The Creole, decided by Mr. Justice Grier, on the circuit, in the year 1853, the subject underwent a learned and thorough examination, both by counsel and the court. ... No American adjudication to the contrary has been brought to our attention." Id. at 66.

37. Justice Swayne did not employ this exact phrasing, but his phrasing of the argument that he rejected clarifies the propriety of this paraphrase. "The argument for the appellants proceeds," wrote Swayne, "upon the general legal principle that one shall not be liable for the tort of another imposed upon him by the law, and who is, therefore, not his servant or agent." $I d$. at 67.

38. Id.

39. 166 Eng. Rep. 619 (Adm. 1842).

40. Id. at 622. Dr. Lushington, Judge of the British High Court of Admiralty, had implied that conclusion in stating that the liability of the ship and the responsibility of the owners were convertible terms.

41. [1868] L.R. 2 Adm. \& Eccl. 3.

42. 74 U.S. (7 Wall.) at 66.

43. Id. at 69 . 
The rule of The China was later discussed by Justice Field in Sherlock $v$. Alling. ${ }^{44} \mathrm{He}$ explained, in dicta, that the relation of master and servant is not changed simply because a shipowner must employ a licensed pilot. "By the common law, the owners are responsible for the damages committed by their vessel, without any reference to the particular agent by whose negligence the injury was committed." "45 The highest courts of the states, sharing this view of the meaning of the China rule, also entertained no doubt that the rule of The China applied in a common law action. In Saulter $v$. New York $\mathcal{E}^{2}$ Wilmington S.S. Co. ${ }^{46}$ for example, the North Carolina Supreme Court rejected the compulsory pilot defense in a common law action and stated that this would be the result even if the state statute had imposed a penalty to enforce the employment of a pilot, rather than simply awarding remuneration to the pilot for services tendered and declined as statutes in earlier cases had provided. ${ }^{47}$ The court explained that the pilot temporarily took the master's place in guiding the ship and that the principle of respondeat superior established the liability of the shipowner for damages negligently caused by either master or pilot. ${ }^{48}$ No reference was made to the treatises on agency or on the law of master and servant, many of which still carried statements of the opposite rule, ${ }^{49}$ but the court quoted extensively from Justice Field's Sherlock opinion. Thus, in its historical context, the rule of The China was grounded in the American common law and was applied by lower courts in suits at law and in admiralty.

\section{Homer Ramsdell Transportation Co. v. La Compagnie Générale Transatlantique (1901)}

A century of judicial unanimity about harbor collisions came to a sudden halt at the beginning of the twentieth century. The Court of Appeals for the Second Circuit certified to the Supreme Court, in Homer Ramsdell Transp. Co. v. La Compagnie Générale Transatlantique, ${ }^{\mathbf{5 0}}$ the question whether in an action at common law a shipowner would be liable for injuries resulting exclusively from the negligence of a compulsory pilot. The underlying problem facing the Court was the validity of the China dictum that the

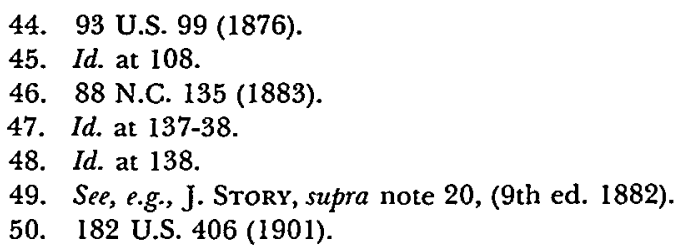


rule must necessarily be the same in admiralty and common law courts. Although the Court never explicitly addressed this question, it apparently concluded that the rule need not be the same.

The case afforded the Court an opportunity to review almost a full century of decisions on the compulsory pilot defense. The attorney for the plaintiff emphasized the British view, consistently followed in the American courts, that whichever rule of liability was reached, it should be the same for both the ship and its owners, regardless of the form of the proceeding. ${ }^{51}$ The argument was logical, but its force was overwhelmed by the lengthy, scholarly brief presented by counsel for the defendant French company. He carefully distinguished between cases of voluntary and compulsory pilotage, and insisted that, with respect to many questions, maritime law constituted a system of jurisprudence distinct and separate from that of commón law. ${ }^{52}$ Since one system differed from the other, it followed that "both rights and forms of procedure [in the one system] . . . are in many.instances not recognized or followed under the other at all." 53

Counsel for the defendant also presented the Court with policy arguments for enunciating differential rules. The earlier opinions in The Creole and The China had both noted that a policy of shipowner immunity would probably leave an innocent party without remedy. The defendant's brief in Homer Ramsdell not only attacked what it termed "the unreasonable and exploded doctrine of $a b$ inconveniente" upon which the earlier choice of rules had rested, ${ }^{54}$ but also suggested that the pilot association of the Port of New York had sufficient resources to respond in damages. ${ }^{55}$ In addition, defendant's counsel argued that the dictum in The China

51. Brief for Plaintiff in Error at 16-18, Homer Ramsdell Transp. Co. v. La Compagnie Générale Transatlantique, 182 U.S. 406 (1901).

52. Brief for Defendant in Error at 46, Homer Ramsdell Transp. Co. v. La Compagnie Générale Transatlantique, 182 U.S. 406 (1901) [hereinafter cited as Defendant's Brief].

53. Id. at 57-58. He argued in part that this was the implication of the China rule, as defined in the dissenting opinion in Ralli v. Troop, 157 U.S. 386, 420 (1894). According to the authors of that opinion, The China established a rule of liability applicable against the vessel alone. See Defendant's Brief, supra note 52, at 42-44, 56. This reading of The China was probably based on Justice Clifford's remarks in his opinion in that case that the owner should be liable only because the American pilotage statutes were not truly compulsory, and did not destroy the relation of master and servant. If the compulsory pilotage statutes did destroy that relationship, as the Ralli $v$. Troop dissenters contended, recovery should be denied against a shipowner in an action at common law. 157 U.S. at 423.

54. Defendant's Brief, supra note 52, at 101.

55. Id. at 114. It was apparently assumed that a pilots' association could be held liable for the acts of one of its members. Later decisions undercut that assumption. See J. GRIFfin, The American Law of Coldision $\$ 189$, at 438 (1949). 
to the effect that the shipowner would also be liable in personam rested upon cases that had since been overruled or reversed. ${ }^{56}$ His focus on the British precedents rather than the American cases enabled him to conclude not only that there was no common law precedent holding a shipowner liable but also that the existing rules of law differed in the two systems of jurisprudence. ${ }^{57}$

A unanimous Supreme Court accepted this argument. In an opinion written by Justice Gray, author of the majority opinion in Ralli $v$. Troop, ${ }^{58}$ which had defined the scope and effect of The China seven years earlier, the Court held that no common law action could be maintained against the owner of a vessel for the negligence of a compulsory pilot. ${ }^{59}$ The Court's decision was supported by a comprehensive review of the English cases cited in the defendant's brief, followed by a reference to Story's treatise. ${ }^{60}$ The narrow and technical format of the opinion averted explicit consideration of policy matters.

The reasoning of Homer Ramsdell has been criticized by leading scholars. ${ }^{61}$ The opinion consists almost entirely of flat statements of propositional law and selected quotations from English and American decisions, ${ }^{62}$ without any apparent attempt to fashion a coherent rationale. The concluding assertion that the second edition of Story's treatise on agency established sufficiently the liability of the owner at common law for the act of a pilot on his vessel takes advantage of an unguarded overstatement by that commentator. ${ }^{63}$ Later editions of the treatise more clearly noted the qualifications that applied to the rule. ${ }^{64}$

In short, the Gray opinion accepted the post-1815 British rule as declarative of the common law and passed over the contrary dicta in both The Creole and The China. Following its more recent

56. Defendant's Brief, supra note 52, at 104-05.

57. Id. at 50 .

58. 157 U.S. $386(1894)$.

59. 182 U.S. at 411,417 .

60. Id. at 416 .

61. See, e.g., Gilmore \& Black, supra note 14, at 430 n.135; W. Seavey, Studies IN AGENCY 227-28 (1949).

62. The Court's quotations in support of its assertion that American decisions holding shipowners liable had dealt only with pilotage statutes that were not truly compulsory, for example, omitted the language of the Saulter case, 88 N.C. 135 (1888). See text at notes 46-48 supra.

63. As quoted, the second edition of Story's treatise stated as the common law liability rule that if a master is required to take a pilot under a penalty, that compulsion precludes viewing the pilot as the servant of either the master or the owner of the ship, and neither master nor owner is liable for the pilot's negligent actions. See 182 U.S. at 416.

64. See J. STORY, supra note 20 , at 595 n.I (3d ed. 1846). 
opinion in Ralli $v$. Troop, ${ }^{65}$ the Court again affirmed the view that The China "proceeded . . . upon a distinct principle of the maritime law, namely, that the vessel in whosesoever hands she lawfully is, is herself considered as the wrongdoer liable for the tort, and subject to a maritime lien for the damages." 66 The opinion remained completely silent on the advantages of applying the same rule regardless of which court takes jurisdiction over the litigation, even though a resolution of that issue was an obvious implication of the decision.

The narrow effect of Homer Ramsdell was the acceptance of British theories of agency. ${ }^{67} \mathrm{By}$ limiting its opinion to a declaration of the common law without construing principles of admiralty, ${ }^{68}$ the Court allowed the compulsory pilot defense when an injured party brought an action at law against the shipowner, while prohibiting the defense in a libel in rem. Underlying this technical answer to the question certified by the court of appeals, however, was an implied policy choice concerning the propriety of imposing vicarious liability. Although the China Court had found it "wise and salutary" for the owners of a colliding vessel to respond in damages, the Court in Homer Ramsdell implicitly reached the opposite conclusion.

The Supreme Court has not directly considered the pilotage defense in the seventy-odd years since Homer Ramsdell. ${ }^{69}$ Courts and commentators have done little more than echo black-letter rules, routinely perpetuating two distinct rules of liability by applying established agency principles in civil actions and resorting to personification in lien executions. ${ }^{70}$ But given the reexamination of these rules called for both by the potential denial of relief to injured plaintiffs and by judicial and scholarly skepticism of the personification doctrine as a conclusory rationale for decision, ${ }^{11}$

65. 157 U.S. 386 (1894).

66. 182 U.S. at 413-14, quoting Ralli v. Troop, 157 U.S. 386, 402-03 (1894).

67. See, e.g., C. Smith, A Treatise on the Law of Master and Servant 327-29 (5th ed. 1902).

68. In making that declaration, the Court failed to distinguish between the common law of the United States and that of Great Britain. It recognized, however, an exact contrariety of the British and American admiralty rules.

69. 182 U.S. 406 (1901).

70. The leading treatises on collision and pilotage set forth the disparate litigation results but do not examine policy grounds for the inconsistency. See, e.g., J. GrifriN, supra note 55, at \$§ 193-94, at 443-47; A. PARKs, supra note 1 , at 486-89. The most recent example of a court's mere recitation of the established rules occurs in United States v. S.S. President Van Buren, 490 F.2d 504, 506-07 (9th Cir. 1973). But see GrLmore \& BlaCK, supra note 14, at 430 n.135; W. SEAVEY, supra note 61, at 224-28.

71. See text and notes at notes 6-15 supra. 
the policy issues underlying the question of liability in the compulsory pilot case must be explicitly reconsidered.

\section{A Critical Examination of Personification and Agency}

The classic personification opinions need not stand as perennial obstacles to realistic jurisprudence, nor need the historic formulations of agency principles obstruct a fresh view of the interaction of legal doctrine with commercial and economic realities. The modern task in compulsory pilot cases is to fashion functionally sound and commercially realistic rules to be applied consistently in both lien proceedings and personal actions. A preliminary review of the law of nations, enterprise liability, and modern principles of agency law suggests the parameters within which a modern synthesis can emerge.

\section{A. The Law of Nations}

Most maritime nations have supported or acquiesced in the uniform rules concerning collisions between vessels established in the Brussels Collision Convention of $1910 .{ }^{72}$ Under these rules, liability attaches to the vessel causing the collision even if it is the result of the sole negligence of a compulsory pilot. ${ }^{73}$

The United States has persistently refused to accept the Brussels Collision Convention. ${ }^{74}$ Ratification by the Senate would preclude judicial adoption of a consistent rule allowing the compulsory pilot defense in both in rem and in personam actions. Indeed, this is substantially what occurred in Great Britain when Parliament, ignoring the language and dicta of nineteenth century jurists, reversed the policy of exempting shipowners for the torts of a compulsory pilot in the Pilotage Act of $1913 .{ }^{75}$ Since Great Britain had long applied a consistent liability rule in all its courts, this reversal of the liability rule merely represented a different policy choice as to which party should consistently bear the loss. ${ }^{76}$

While a judicial acceptance of the compulsory pilot defense in all forms of proceeding is not thus directly precluded in the

72. International Convention for the Unification of Certain Rules of Law with respect to Collisions between Vessels, Signed at Brussels, September 23, 1910, [1913] Gr. Brit. T.S. No. 4 (CMD. 6677) at 41, 7 Martens Nouveau Recueil (ser. 3) 711. This treaty is popularly known as the Brussels Collision Convention of 1910.

73. Id. at 51 (Article 5), 7 Martens Nouveau Recueil (ser. 3) at 720.

74. See H. Baer, Admiralty Law of the Supreme Court 414 (1969).

75. $2 \& 3$ Geo. 5, c. $31, \S 15$.

76. It should be noted that the Pilotage Act of 1913 was subject to certain geographical and other limitations that might allow some inconsistency of result. See 23 HalsBury's StatuTES OF ENGLAND 844 (R. Burrows ed., 2d ed. 1950); Richards, supra note 7, at 577 n.72. 
United States by legislative ratification of the Brussels Collision Convention, a liability rule that is consistent with the rule in force in most other maritime nations is to be favored over one that is not. Thus, in questioning whether any basis of liability may be identified for the owner of a damaging vessel in terms either of commercial necessity or of principles of agency, this international law factor must also be considered.

\section{B. Enterprise Liability}

The basic goals of modern tort law include compensation of victims, reduction in the number or magnitude of accidents, and distribution of the costs of compensation. ${ }^{77} \mathrm{~A}$ primary reason for reexamining the long standing rules of liability in harbor collisions is their potential failure to fulfill the first criterion, compensation of victims. As a result of the Homer Ramsdell decision, ${ }^{78}$ innocent victims may go uncompensated if they are unable to sue in rem. A new scheme of liability may be formulated that will eliminate the potential for this result, but that new scheme must also fulfill the other two tort goals, reduction of accidents and distribution of cost.

One possible alternative scheme would be judicial recognition of the compulsory pilot defense in both in rem and in personam actions, thus placing exclusive liability on compulsory pilots for their negligence. Although these pilots may be sued under current liability rules, the remedy is rarely sought because pilots are generally judgment proof. ${ }^{79}$ Even assuming that this problem of failure to compensate victims were solved under the current system by a legislative requirement of liability insurance for pilots, a scheme of exclusive liability would seem to be preferable because it would place the burden of loss upon the negligent parties.

The accident preventive effect of this allocation of the burden, however, may be diminished in actual operation. The burden of loss would be spread among all pilots who pay for liability insurance, and although a claim on a policy would raise a negligent pilot's premium rate, the accident preventive burden is cushioned to some extent. The burden is further removed from the individual pilot because his insurance costs are likely to be paid by his pilot association, which probably pools expenses and revenues, ${ }^{80}$

77. See Posner, $A$ Theory of Negligence, $1 \mathrm{~J}$. LeGal Studies 29, 30-31 (1972).

78. 182 U.S. 406 (1901).

79. See A. PARKS, supra note 1 , at 484 .

80. See id. at 506 . 
and even to be passed on to shipowners by the association in the form of increased pilotage fees. ${ }^{81}$ Pressure might be directed at the negligent pilot through various sanctions imposed by his association, such as adjustments in his share of the income pool, but the system causes the accident preventive effects of an exclusive liability rule to operate only indirectly against the individual negligent pilot.

The other alternative scheme, precluding use of the compulsory pilot defense in both in rem and in personam actions, may also have accident preventive effects. The ship's master, who is the shipowner's agent, has a well established right to supersede the pilot if he believes the pilot's actions will cause a collision. ${ }^{82}$ A rule of shipowner liability would promote a more vigilant exercise of this right than would a rule placing exclusive liability on the negligent compulsory pilot. The net accident preventive effect of the latter rule is likely to be greater, however, subject to the qualifications previously discussed.

Under either scheme, the ultimate burden of the loss would probably be spread among the users of the shipping industry. Pilot associations would pass on the costs of liability insurance to shipowners through increased pilotage fees. Shipowners would pass on either increased pilotage fees, or under the other rule of liability the cost of their own insurance, to their shippers. Thus, neither scheme appears to produce a more advantageous ${ }^{83}$ or broader distribution of collision losses.

A scheme that gives effect to the compulsory pilot defense, however, would produce unnecessarily higher costs. Protection and indemnity insurance is already in universal use by shipowners. ${ }^{84}$ The assessment of exclusive liability upon negligent compulsory pilots would require the establishment of a new system of pilots' insurance to provide compensation for injured plaintiffs. But the shipowners' insurance system would not be supplanted by the new system, because the pilotage statutes of some

81. See id. at 505; Zammit, The Validity of the "Pilotage Clause" in Docking Assistance Contracts, 3 J. MARITIME L. \& Com. 71, 83 (1971).

82. A. PARKs, supra note 1 , at 481 .

83. "[T] $]$ he most desirable system of loss distribution under a strict resource-allocation theory is one in which the price of the goods accurately reflect their full cost to society. The theory therefore requires, first, that the cost of injuries should be borne by the activities which caused them." Calabresi, Some Thoughts on Risk Distribution and the Law of Torts, 70 YALE L.J. 499, 505 (1961).

84. "[L]iterally every ship being piloted has already procured P \& I insurance insuring the liability of its owner to third parties for negligent acts of its master, crew, and pilots." A. PARKs, supra note 1 , at 505 (emphasis in original). 
American ports have been held not to be legally compulsory,${ }^{85}$ and shipowners would thus have no defense for damages resulting from collisions caused solely by the negligence of "voluntary" pilots in those ports. Assuming that trip-by-trip insurance coverage, with premiums determined according to the pilotage rules of each port, would be too costly to administer, some degree of double insurance coverage would result. ${ }^{86}$ The certain increase in overall cost involved in this double coverage may outweigh the possibility of accident prevention produced by allowing a compulsory pilot defense. A consistent rule of shipowner liability would spread the loss at lower overall cost, and with some degree of accident preventive effect.

\section{The Restatement of Agency Compromise-Section 223}

A rule declaring that the statutory compulsion to employ a licensed pilot does not destroy the relation of master and servant results in a single liability rule at law and admiralty and is consistent with broader rules of agency law. Indeed, the nineteenth century American courts consistently found an agency relationship in spite of the compulsory nature of the employment. ${ }^{87}$ In the twentieth century, the American Law Institute adopted a comparable approach. ${ }^{88}$ Section 223 recognized a master's liability for the torts of a servant even though there is only a single qualified or licensed individual whom the employer may hire. ${ }^{89}$ Universal application of this section would eliminate the inconsistent results that American precedents now require.

Deferring to established cases, however, the Restatement of Agency would permit the raising of a compulsory pilot defense. The reporter for the Restatement, Professor Seavey, found the reasoning of Homer Ramsdell unsatisfactory and formulated the

85. See, e.g., United States v. S.S. President Van Buren, 490 F.2d 504, 507 (9th Cir. 1973).

86. Although overall protection and indemnity insurance costs under this scheme should be less than under a scheme that does not recognize the compulsory pilot defense, the decrease would probably not match the reduction in shipowner's liability precisely, given the uncertainties of the number of times insured ships would use voluntary or compulsory ports and the possibility of changes in the rules of various ports.

87. See text and notes at notes 19, 46-48 supra.

88. "The relation of master and servant may exist although the law requires the selection of persons for the particular work to be made from a limited class irrespective of how limited the class is, and the master is subject to liability for torts committed within the scope of employment by servants from such a class." Restatement (SECOND) OF AGEncy $\S 223$ (1957).

89. See id. at comment b. 
basic rule without exceptions. ${ }^{90}$ The official comment, however, expressly noted that

the shipowner is not liable for the negligence of the pilot in the navigation of the ship, if the effect of the pilotage statutes is to remove control over the navigation of the ship from the shipowner and place it entirely in the pilot. In such case, the relation of master and servant does not exist between such owner and the pilot. ${ }^{91}$

Examination of the independent commentary of Professor Seavey reveals that the Restatement section 223 was a compromise resulting from his analysis of the Homer Ramsdell case. Seavey rejected Justice Gray's position that shipowners' nonliability stemmed from the statutory compulsion to employ the pilot. $^{92}$ "The real problem would seem to be whether the employer has in fact control over the one employed." ${ }^{33}$ Lack of actual control over the employee, rather than loss of the selection opportunity, becomes the Restatement ground for exonerating the owner. ${ }^{94}$ Use of the Restatement to support a general exception to the maxim respondeat superior rests on the mistaken assumption that the legal effect of compulsory pilotage statutes is necessarily to relinquish complete control over navigation to the pilot. Although a master acts at his own peril in superseding the pilot, his right to do so is well established. ${ }^{95}$ Accordingly, the China result could be reached on modern agency principles.

Even if a shipowner is found to have neither selection opportunity nor actual control, grounds for finding a relationship of master and servant may exist. The law of agency often treats an individual as the agent of another even where there has been no consent to the agent's assuming that role. ${ }^{96}$ Similarly, the law has recognized that even while relinquishing actual control to a compulsory pilot, the master of a vessel has the right, and sometimes the duty, to resume command..$^{97}$

90. See W. SEAVEY, supra note 61 , at 226-28.

91. Restatement (Second) of Agency § 223, comment c (1957).

92. W. SEAVEY, supra note 61 , at 224-25.

93. Id. at 226.

94. When read apart from Seavey's independent commentary, the Restatement comments do not make the essential ground this clear. But their reference to pilotage statutes effectuating the removal of control over navigation, when placed against Seavey's characterization of "the real problem," amply support this proposition.

95. See A. Parks, supra note I, at 481.

96. C. Fridman, The LaW of Agency 39 (3d ed. 1971).

97. A. PARKs, supra note 1 , at 481 . 


\section{CoNCLUSION}

The inconsistency of exempting a shipowner from liability for damages caused by the negligence of a compulsory pilot while holding the ship he owns liable should be eliminated, and the fiction that produces the inconsistency should be obliterated where it serves no rational purpose. A close analysis of the original compulsory pilot cases reveals the use of the personification fiction in Homer Ramsdell in place of explicit consideration of a policy choice that underlay a rejection of the China rule. A preliminary consideration of the relevant policy issues indicates that a rule of shipowner liability would be in consonance with the law of other maritime nations, with commercial needs and realities, and with modern principles of agency law. Reversal of the Homer Ramsdell rule, then, would establish a consistent rule of liability without resort to the doctrine of personification as a conclusory rationale. 